\title{
Três poemas de futebol
}

\section{Kaio Carmona}

Dois dos poemas que aqui se apresentam foram publicados no livro Para quando (Scriptum, 2017), os sonetos "Desmedida" e "Uma e outra", e o outro, sem título, na antologia Pelada poética (Scriptum, 2014).

Nesses três poemas, Kaio Carmona liga o futebol ao erotismo (ludos e eros), não definindo precisas regras entre o jogo da bola e o jogo

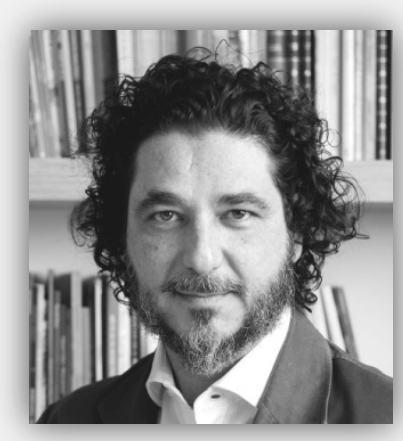
erótico, porque ambos movidos pelo prazer - "Se a uma me entrego nos carinhos / de mesa e cama, à outra me dou / nos fins de semana".

Kaio Carvalho Carmona nasceu em Belo Horizonte, em 1976. É professor, pesquisador e poeta. Graduado em Letras, mestre e doutor em Estudos Literários pela UFMG, onde realiza pesquisa de pós-doutorado sobre a poesia de Affonso Ávila.

Autor dos livros de poesia Para quando (2017) e Compêndios de amor (2013), ambos pela Scriptum de Belo Horizonte. Publicou também Um lírico dos tempos: erotismo e participação social na poesia de Vinicius de Moraes (2006), pela Scortecci de São Paulo.

Atualmente, é professor visitante do Instituto Federal de Educação, Ciência e Tecnologia de Minas Gerais (IFMG) e professor da Faculdade Jesuíta de Filosofia e Teologia (FAJE).

\section{Imagino a bola}

parada,

plena de si.

Oblíqua em gramado azevinho.

Na bola tudo é certeza

e seriedade.

Mesmo com a pouca roupa que lhe cabe

a bola cai em si, sempre,

com seriedade.

Mesmo na expectativa do chute,

no intervalo do fôlego para o impacto,

a bola não treme.

Não.

Senhora firme e delicada,

prefere mover-se sozinha

na conversa com o vento,

no chamado da grama que se dobra à sua passagem.

Mas permanece obstinada ao destino que lhe cabe:

conhecer, aos pulos, os pés, os corpos dos homens

que se lançam a ela

com fúria e paixão.

Ver debaixo

os homens que a ela se lançam

e a esquecem, sempre,

no chão. 


\section{Desmedida}

E se no amor existisse medida, regras definidas como num jogo de futebol? Seria essa saída ou não mais que outro engodo?

E se no amor, jogo sem empate, a partida fosse a vera vitória e coubesse aos amantes a glória de viverem o doce e duro embate

disputado entre amantes inimigos. Ah, mas me esqueço da questão que faz dos dois, distantes amigos.

Não se joga nem se ama com a razão ou um sem número de regras definidas. Para os dois, basta o fôlego da paixão.

\section{Uma e outra}

Amo o que é dela, de minha amada, mas também amo o que é da outra. Não acredite com isso que a pouca imagem que lhe desenho é nada.

Se a uma amo a silhueta delicada, o felino passo e a sua voz rouca; à outra amo a sua pouca roupa, as formas redondas, desenhadas.

Se a uma me entrego nos carinhos de mesa e cama, à outra me dou nos fins de semana, em tapete azevinho.

E com ela ensaio uma dança embolada. Confesso aqui meu amor ao futebol e o prazer de jogar uma boa pelada. 